\title{
MĂRTURII ALE LITERATURII PENTRU ISTORIA LIMBII ROMÂNE
}

\author{
Inga DRUȚĂ \\ Institutul de Filologie Română „Bogdan Petriceicu-Hasdeu”, Chișinău
}

Rezumat. Înjumătatea a doua a secolului al XIX-lea apar primele romane românești, care, deşi inegale ca realizare, reprezintă un document al vremii şi furnizează şi astăzi informaţii preţioase privind circulaţia, semnificaţia şi forma unor cuvinte. În lucrare se analizează stratul lexical al romanului Ciocoii vechi și noi de Nicolae Filimon. Stăpânirea fanariotă din Moldova și Țara Românească și-a lăsat amprenta nu numai sub aspect social și moral, ci și lexical. Atmosfera romanului este țesută în majoritate din cuvinte de origine turcă și neogreacă, specifice epocii descrise. Acestea denumesc funcții, ranguri și ocupații, instituții, piese de vestimentație, stofe, feluri de mâncare, calități și defecte umane ș.a., constituind o radiografie a epocii sub aspect etimologic.

Cuvinte-cheie: literatura română, istoria limbii române, etimologie, semnificație, fond lexical.

Abstract. In the second half of the 19th century, the first Romanian novels appear, which, although unequal in their realization, represent a document of time and still provide valuable information on the circulation, meaning and form of words. The paper analyzes the lexical layer of the novel Ciocoii vechi și noi by Nicolae Filimon. The Phanariot domination of Moldova and Wallachia left its mark not only from a social and moral aspect, but also from a lexical one. The atmosphere of the novel is woven mostly of words of Turkish and Neo-Greek origin, specific to the described era. They gave names to functions, ranks and occupations, institutions, clothing, fabrics, dishes, human qualities and defects, etc., constituting a radiograph of the era from an etymological point of view.

Keywords: Romanian literature, history of the Romanian language, etymology, meaning, lexical background.

În epoca modernă (1780-1860) de dezvoltare a limbii române apar primele manuale, primele publicații periodice și primele dicționare. Se diversifică creațiile literare - de la poezie și nuvele la eseuri și opere dramatice. La sfârșitul perioadei apar primele romane în limba română: Manoil de Dimitrie Bolintineanu (1855), Coliba Măriucăi de V.A. Urechia (1855), Un boem român de Pantazi Ghica (1860). 
Primele romane românești, deşi inegale ca realizare, reprezintă un document al vremii şi furnizează şi astăzi informaţii preţioase privind atestarea, circulaţia, semnificaţia şi forma unor cuvinte și expresii.

În 1863 apare primul roman realist din literatura română, Ciocoii vechi și noi de Nicolae Filimon, „un muzeu viu al istoriei românești” (George Ivașcu), cu referire la o perioadă mai timpurie: 1814-1825. Este curios faptul că autorul a adnotat scrierea, conștientizând că unele cuvinte sau expresii nu ar fi pe înțelesul cititorului din jumătatea a doua a secolului al XIX-lea, prin urmare, o parte din lexemele întâlnite în roman deja ieșeau din uz în momentul apariției romanului.

Stăpânirea fanariotă din Moldova și Țara Românească și-a lăsat amprenta nu numai sub aspect social și moral, ci și lexical. Naratorul romanului și personajele sale bântuie într-o atmosferă țesută în majoritate din cuvinte de origine turcă și neogreacă, specifică epocii descrise. Acestea denumesc funcții, ranguri și ocupații, instituții, piese de vestimentație, stofe și blănuri, băuturi și feluri de mâncare, calități și defecte umane ș.a.

În roman am găsit o mulțime de denumiri de ocupații: abagiu „fabricant sau negustor de aba”; binişliu „purtător de biniș; curtean”; bogasier „,negustor de manufactură”; bragagiu ,persoană care face sau vinde bragă”; calemgiu „,copist, funcționar”; capugiu ,trimis al sultanului în țările române, împuternicit în special cu schimbarea domnilor"; cămăraș, ,slujbaș care avea în grijă odăile domnului, în special cămara domnească”; ciohodar „slujbaș care îngrijea de încălțămintea domnului și a curții; lacheu”; ciubucciu ,slujitor care avea însărcinarea să umple și să aprindă ciubucul domnului sau al boierilor"; dărvar (și dârvar) „slugă care avea obligația de a aduce stăpânului lemne din pădure și a se îngriji de încălzirea camerelor”; elciu „ambasador, consul”; găitănar „,fabricant sau negustor de găitane”; iamac ,,ajutor de logofăt”; ibrișimgiu „fabricant sau negustor de ibrișin”; iciolan „paj, copil de casă”; idicliu „,slujitor la curtea domnească”; imbrohor ,,persoană trimisă de sultan în țările române cu înalte misiuni politice”; lipscan ,negustor care vindea pe piețele românești mărfuri aduse de la Lipsca (Leipzig)”; masalagiu „purtător de torțe”; medelnicer ,titlu dat în Evul Mediu, în Țara Românească și în Moldova, boierului care turna domnului apă ca să se spele pe mâini și servea bucatele"; mumbaşir "(în Evul Mediu, în Țara Românească și în Moldova) slujbaș însărcinat cu încasări și cu execuții fiscale”; nefer „oștean”; peșchegiu „funcționar al seraiului care era însărcinat cu perceperea tributului și cu păstrarea darurilor făcute sultanului”; pitar „titlu dat boierului care se ocupa de aprovizionarea cu pâine a curții domnești și a oștirii, precum și cu supravegherea brutarilor domnești”; salepgiu ,persoană care prepară sau vinde salep”; sameș „,funcționar administrativ din trecut, îndeplinind funcția de contabil, casier și strângător de biruri pe județ”; satiraș ,slujitor înarmat 
din garda domnească”; seimean (și seimen) „soldat din corpul de ostași mercenari pedeștri înarmați cu sânețe, a căror atribuție era paza curții domnești”; serdar „(în sec. XVII-XVIII, în Țara Românească și Moldova) comandant de oaste, mai ales de călărime; boier de rang mijlociu”; simigiu „covrigar”; sluger „,dregător în țările române însărcinat cu aprovizionarea curții domnești și a armatei”; sofragiu (și sufragiu) „om de serviciu care servea la masă”; șătrar „titlu dat boierului care avea în pază corturile unei tabere în timp de război”; taxidar ,,persoană care strângea dările”; tefterdar (și defterdar) „,controlor financiar al vizirului sau al unui pașă; perceptor"; telal ,negustor ambulant (de haine vechi); persoană care făcea strigările la un mezat"; tufecciu ,soldat mercenar din garda domnească, în timpul domniilor fanariote”; vătaf ,(în Evul Mediu, în Țara Românească și Moldova) supraveghetor al slugilor de la curtea unui boier sau de la o mănăstire; logofăt”; zapciu „,cârmuitor al unei plăși, subordonat ispravnicului (și însărcinat cu strângerea dărilor); agent de poliție; sergent de stradă”; zaraf „,persoană care se ocupa cu schimbul banilor; cămătar; casier al vistieriei”.

Din acest noian de ocupații și ranguri uitate, abagiu, binişliu, calemgiu, capugiu, ciohodar, ciubucciu, elciu, iamac, ibrișimgiu, iciolan, idicliu, imbrohor, mumbașir, nefer, peșchegiu, salepgiu, seimean, serdar, simigiu, sofragiu, taxidar, tefterdar, telal, tufecciu, zapciu și zaraf sunt de origine turcească, iar masalagiu provine din neogreacă.

Majoritatea acestor cuvinte au ieșit din uz (cu excepția lui simigiu și peșchegiu cu sensul de ,chilipirgiu”), dar unii termeni circulă și astăzi ca nume proprii: Abagiu, Bogasieru, Bragagiu, Ciohodaru, Ciubucciu, Serdaru, Pitar, Vătavu, Zarafu, iar în centrul istoric din București există o splendidă stradă numită Lipscani.

După incursiunea în universul numelor de ocupații, să vedem ce purtau boierii și boieroaicele, dar și servitorii lor, acum două sute de ani: anteriu „haină lungă”; biniş „,haină lungă și îmblănită, purtată mai ales la solemnități”; caravani ,pantaloni largi în talie și strâmți de la genunchi în jos, strânși la glezne cu nasturi sau cu copci”; cauc „căciulă înaltă din pâslă”; ceacșiri ,pantaloni turcești largi”; conteș „haină lungă îmblănită, purtată odinioară de boieri”; dulamă „haină de ceremonie din stofă scumpă”; feregea ,,mantilă de vară”; fermenă (și fermenea) ,haină scurtă făcută din stofă brodată cu fir sau cu mătase, uneori căptușită cu blană, pe care o purtau în trecut boierii peste anteriu”; giubea „haină lungă și largă din postav (fin), adesea căptușită cu blană, purtată, în trecut, de boieri”; gugiuman ,căciulă de samur purtată, în trecut, de domni și de boieri, ca semn al demnității lor”; ipingea „manta bărbătească făcută din dimie sau din postav (cu glugă și împodobită cu găitane)”; işlic „,căciulă de blană scumpă sau de postav, de format mare, cilindrică sau cu fundul pătrat (din alt material), purtată de domni, de boieri și uneori de soțiile lor, iar mai târziu de negustori, de lăutari”; libadea „,haină bărbătească lungă, 
confecționată din material gros, purtată la început de boieri și apoi de orășeni"; malotea „haină femeiască lungă până la pământ, de obicei căptușită cu blană scumpă, având marginile din față, gulerul și manșetele tivite cu blană; scurteică purtată de țărănci în zilele de sărbătoare”; mintean ,haină bărbătească scurtă, cu sau fără mâneci, din dimie, de obicei împodobită cu găitane, folosită în portul popular; pieptar sau tunică de stofă colorată, purtată în trecut de arnăuți sau de alte categorii de ostaşi”; sangulie ,năframă din țesătură foarte fină (de mătase)”; simizet „un fel de ie"; tătarcă ,învelitoare a capului”; iminei ,pantofi de modă turcească, cu căputa înconjurând călcâiul, făcuți din marochin și purtați odinioară de boieri; pantofi cu vârful ascuțit, purtați în trecut de țărani”; meși „,cizmulițe fine”.

Și în această serie predomină turcismele: anteriu, cauc, ceacşiri, dulamă, feregea, fermenea, giubea, gugiuman, ipingea, ișlic, libadea, malotea, mintean, iminei, meși. Cuvântul caravani este de origine bulgară, conteș vine din poloneză sau maghiară, simizet - din franceză, iar sangulie are etimologie necunoscută.

Și dacă astăzi se poartă în special denim, bumbac, lână, viscoză sau fibre sintetice cu diverse denumiri, acum două sute de ani negustorii din țările române vindeau alagea ,stofă vărgată de mătase”, bibiluri sau blondură „dantelă”, bogasiu „stofă sau pânză fină importată din Orient și întrebuințată mai ales pentru căptușeli”, buhur „,cașmir”, camohas ,stofă de mătase orientală”, canavăț „,pânză rară din mătase”, cutnie ,țesătură din mătase și bumbac”, hataia „stofă fină de mătase”, maniţă „stofă ușoară”, sandal „stofă de mătase”, tulpan „muselină”. Alagea, bogasiu, buhur, cutnie, hataia, sandal sunt turcisme, bibiluri, camohas, canavăț și tulpan sunt de origine neogreacă, iar maniță are o etimologie necunoscută.

În roman, Nicolae Filimon oferă informații detaliate despre viaţa la curțile boierești și la curtea domnească, ierarhia servitorilor și funcționarilor, viața culturală și muzicală a vremii, arhitectura orașului București și interioarele clădirilor din acea vreme. Într-o plimbare imaginară din primele decenii ale secolului al XIX-lea prin București, cititorul ar zări agia (poliția de astăzi), calemul (birourile administrației publice), grămăticia (cancelaria domnească), hătmănia (conducerea hatmanului), spătăria (închisoarea), iar mai la periferii, vreo carvasara (local cu birourile unei vămi) sau mai multe capanuri (magazii de aprovizionare). Personajele, în goană după ,avere și mărire”, sunt mereu în căutarea unui huzmet sau mansup (astăzi se spune job), iar pentru o slujbuşoară, nu era suficient un regealâc (rugăminte), ci se impunea și un substanțial ruşfet (mită). Iar dacă un ipochimen ajungea de la asopism (preocupare adâncă) la aporie (încurcătură), apoi la apelpisie (disperare), în dorinţa lui de a parveni, recurgea și la alte mijloace, cum ar fi intrigile și pâra cu baseță (josnicie), fără să-i pese de itichi (morală sau virtute): „Fanariotul nostru exploată cât se putu mai bine postul de cămăraş, iar când văzu că în cămară nu mai rămăsese nimic de furat, cumpără mai întâi calemul vinăriciului, al oieritului şi mai în urmă 
huzmetul spătăriei; şi astfel, unindu-se cu hoţii şi tâlharii de drumuri, despuie ţara în toate modurile mai mult de trei ani, până ce îşi cumpără vreo zece moşii, câteva familii de ţigani, case, vii şi altele; iar după aceea izbuti, tot prin intrigă şi baseţă, a deveni mare postelnic" (p. 14). Astfel, ajuns cilibi (stimat, distins), arhon (domn) postelnic, începe să primească rugăminți și pentru alții: „Alta am să te rog, arhon postelnice: fiul meu, înfăţişătorul acestei umilite scrisori, a ajuns în ilichie (vârstă n.n.) şi cu toate că m-am silit a-l învăţa toate iuşchiuzarlâcurile (șiretenie, meșteșug n.n.) şi marafeturile (tertipuri, înșelătorii - n.n.) cu care trebuie să fie împodobit un adevărat calemgiu, dar nefiind de ajuns toate acestea, îl trimit la Domnia Ta ca să se mai roadă, ca să poată ieşi şi el mâine-poimâine la obraze" (p. 9). Așa se rezolva o madea (chestiune, afacere): ba cu o brașovenie (marfă de Brașov), ba cu un chilim (covor turcesc cu două fețe), ba cu o teșcherea (pungă) plină cu mahmudele (bani)... Și așa, omul ajungea isnaf (breslaș), se umplea de capioldași (amici), vâna un havadiș sau o mujdea (veste) despre cine știe ce ghelir (câștig neașteptat) și aștepta vreun pitac (decret) domnesc de căftănire (boierire). Și atunci să vezi! Economie maximă la imiclic (tainul zilnic al servitorilor), dar firoseală (risipă) de poveste la o englingea (petrecere). De fapt, se cumpărau și cărți, nu numai plăceri culinare: „Pe acei timpi, ca şi în zilele noastre, bibliotecile erau la modă; toţi junii muchelefi (fercheși - n.n.) şi spudaxiţi (cultivați - n.n.) aveau câte o bibliotecă formată din cele mai bune cărţi ale timpului, pe care nu le citeau niciodată” (p. 36).

Cuvintele evidențiate au ieșit din uz (cu excepția lui ipochimen), fiind înlocuite, cu timpul, de elemente de origine franceză, italiană, germană, iar ulterior, engleză. Agie, calem, capan, capioldaş, carvasara, chilim, englingea, ghelir, havadiş, huzmet, imiclic, isnaf, iuşchiuzarlâc, madea, mahmudea, mansup, muchelef, mujdea, regealâc, rușfet, teșcherea sunt de origine turcă; arhon, asopism, aporie, apelpisie, firoseală, ilichie, ipochimen, itichi, marafet, spudaxit provin din neogreacă; pitac este slavonism, iar grămăticie, hătmănie și spătărie sunt creații pe teren românesc.

Dar să revenim la petreceri și să vedem ce bucate se serveau la mesele boierești acum două sute de ani: „Pe masă erau rânduite o mulţime de farfurii cu mezelicuri de tot felul: marinată de stacoji (raci-de-mare-n.n.), (...) icre proaspete de morun, licurini jupuiţi, sardele muiate în untdelemn de Mitilene amestecat cu piper şi zeamă de lămâi de Messina, măsline dulci de Tessalia, grămădite în formă piramidală, icre tari de chefal, smochine de Santorini, halva de Adrianopole..." (p. 93). Iar după mezelicuri, ,ei puseră pe masă un castron colosal plin cu ciorbă de ştiucă fiartă în zeamă de varză cu hrean; pe urmă aduseseră două farfurii lunguiețe cu mihalţi şi păstrăvi rasol, muiaţi în oţet şi untdelemn; aduseră mai multe vase de cositor pline cu iahnii, cu plachii, cu morun gătit în măsline şi foi de dafin, cu crapi umpluţi cu stafide şi coconare (sămânţă cu gust de alune a unui soi de pin - 
n.n.) şi alte felurite mâncări care se ziceau în vechime «bucate cu cheltuială»" (p. 94). Se mai serveau chebapuri (,fripturi turcești”, după cum adnotează autorul), ciurechi (,un fel de cozonaci”) și, la sfârșit, felegene (ceșcuțe turcești) nenumărate de cafea...

Printre formulele de adresare din roman (și, implicit, din epocă) erau arhon (titlu de politețe pentru un boier), chir (domn, $n g r$.), chera (doamnă, $n g r$.), panevghenie (domn/doamnă, ngr.) ș.a. Iată un exemplu de dialog din roman: „În fine, cocheta îşi alegea un inel de diamant, de mărgăritar sau o perniţă de odagaciu şi zicea surâzând: - Cât costiseşte aceasta, chir Costeo? - Să fac socoteala, milostivo. Apoi luând în mâini obiectele în chestiune, se prefăcea că se gândeşte la preţul lor şi-n urmă răspundea cu aer meditativ şi serios: - Pe mine mă ţin şapte sute de lei, dar pentru preacinstitul obraz al panevgheniei tale le dau tot cu acest preţ, voiesc să mă fac om al casei domniei sale" (p. 52).

După cum se observă, limbajul romanului furnizează unui cercetător din prezent nu numai lexeme și semnificații, ci și forma unor termeni, adică informații morfologice (conjugarea verbului $a$ costa, în exemplul citat).

Autorul explică și unele expresii idiomatice, cum ar fi a da pe pârlitură „a descoperi sau a demasca pe hoți” sau altă căciulă: „De va fi existat teatru în ţara noastră înainte de Caragea, nu ştim, istoria nu ne spune nimic; chiar tradiţiunile populare nu ne arată decât venirea unor escamatori arabi şi turci, care scoteau panglice din guri, înfigeau ace prin muşchii mâinilor, vărsau mei pe nas şi scoteau din cap o mulţime de căciuli” (p. 103), frază adnotată astfel: „De la acei scamatori a rămas vorba populară altă căciulă".

Sintetizând, susținem că operele literare, pe lângă documentele istorice ale vremii, furnizează şi astăzi informaţii relevante privind atestarea, circulaţia, semnificaţia şi forma unor cuvinte și expresii, care sunt, cu timpul, înregistrate în dicționare și în gramatici.

\section{Referințe bibliografice:}

1. FILIMON, Nicolae. Ciocoii vechi și noi. București: Albatros, 1970.

2. Micul dicționar academic (ediția a II-a). București: Academia Română, Institutul de Lingvistică, Univers Enciclopedic, 2010.

Notă: Articolul a fost realizat în cadrul proiectului de cercetare 20.80009.1606.01 Valorificarea științifică a patrimoniului lingvistic național în contextul integrării europene, Institutul de Filologie Română „B. P.-Hasdeu” al MEC. 